\title{
Enterococci Isolated from Japanese Quails Exposed to Microgravity Conditions and Stability of their Properties
}

\author{
Andrea Lauková, Gabriela Michlovičová \\ Institute of Animal Physiology, Slovak Academy of Sciences, Košice, Slovakia
}

Received July 1, 2008

Accepted February 9, 2009

\begin{abstract}
Enterococci isolated from the crop and caecum of Japanese quails exposed to 7 day conditions of microgravity were re-vitalized after their dry-freezing long storage. Originally, the strains were isolated from Japanese quails after their landing from flight onboard the orbital station Mir during the experiment in August 1990. Because taxonomy as well as the studies concerning the bacteriocins, especially those produced by enterococci, have been continually developed for years, the aim of this study was to confirm species identification, stability of the properties of enterococci as well as to test new properties after their long storage. Genotyping allotted the strains to the species E. faecium. Lactic acid production was detected in similar amounts in the strains before and after their long-storage in dry-frozen form. The strains were vancomycinsensitive and kanamycin-resistant before as well as after their long-time storage. Variability in sensitivity to different antibiotics was found among the strains tested even before and after longtime storage. Each of the strains possessed at least one structural enterocin gene. The structural genes for enterocin A, P, B, L50B were detected in E. faecium EP7. E. faecium EP2, EEP4 have the genes for ent A, B, L50B. The gene for ent P was detected only in the strain EP7. The most often detected was ent A gene followed by ent genes B, L50B. All strains inhibited growth of at least 4 out of 15 indicators. The stability of the enterococcal properties determined before as well as after their dry-freezing was not influenced during their long-term storage; moreover, new properties were determined.
\end{abstract}

Enterococci, storage, enterocin gene, properties, stability

Japanese quails represent suitable animal laboratory model for several reasons: their small size, low husbandry costs, short generation interval and adaptability to a wide range of husbandry conditions. Therefore, in past they were an object of the scientific space research programme (Bod'a 1979) called Interkozmos that was finished in 1990 s. In this programme many research issues were investigated and solved; e.g. the effect of microgravity on endocrine functions and adaptation processes (Juráni et al. 1988), embryonic development (Bod'a et al. 1992) and/or morphological changes in the small intestine under space-flight conditions (Cigánková et al. 2000). Moreover, in the framework of the Interkozmos programme-Incubator 2, firstly also microflora of Japanese quails exposed to microgravity conditions was analysed in comparison to conventional Japanese quails with an impact on lactic acid bacteria such as lactobacilli, enterococci and staphylococci (Lauková et al. 1991, 1993a, 1995). The most studied were enterococci that were also found to produce antimicrobial substances - bacteriocins (Lauková et al. 1993bc). The studied isolates were dry-frozen and stored for a long period for other tests. Because taxonomy as well as the studies concerning bacteriocins, especially those produced by enterococci, were continually widely developed for years and enriched with new knowledge (Aymerich et al. 1996; Casaus et al. 1997; Cintas et al. 1998, 2000; De Vuyst et al. 2003; Mareková et al. 2007; Franz et al. 2007), the aim of this study was to confirm the species identification, stability and properties of enterococci after their long-time storage as well as to genotype them and to test them for the previously not determined properties.

Address for correspondence:

MVDr. Andrea Lauková, PhD.

IAP SAS, Šoltésovej 4-6

04001 Košice

Slovakia
Phone:+421-55-633 0283, 7922964

Fax:+421-55-7287842,

E-mail:laukova@saske.sk

http://www.vfu.cz/acta-vet/actavet.htm 


\section{Materials and Methods}

Six strains of enterococci isolated from the crop (EEP4, EP2) and caecum (EFP7, EP7, EFP4, EFP5) of Japanese quails exposed to 7 days of microgravity conditions were re-vitalized after their long-time dry-freezing storage (18 years). Originally, the strains were isolated from Japanese quails after their flight onboard the orbital station Mir during the experiment carried out in August 1990. The samples were treated as described previously (Lauková et al. 1991). Dry-frozen strains were cultivated in the Brian Heart Infusion (Becton \& Dickinson, Cockeysville, USA) for $18 \mathrm{~h}$ at $37^{\circ} \mathrm{C}$. Then they were plated onto M-Enterococcus agar as well as Brian Heart agar supplemented with defibrinated sheep blood to check their purity. In the past, the strains were phenotyped by the API 20 Strep identification kit (BioMeriux, l'Etoile, France) and analysed to produce lactic acid (Pryce 1969) have bacteriocin-like activity (Skalka et al. 1983) and tested for sensitivity/resistance to antibiotics (NCCLS 2002). After their re-vitalization, they were genotyped using primer sequences and PCR method (Woodford et al. 1997) to confirm their taxonomy. Beside the above-mentioned tests, they were tested for possession of structural genes for enterocin production, and their antimicrobial activity was tested against additional indicator organisms (Table 2).

To detect the structural genes for enterocin production, $2 \mu \mathrm{l}$ of template was added to $8.75 \mu \mathrm{l}$ of the reagent mixture which contained $0.5 \mu \mathrm{l}$ each of the primers, $1 \mu \mathrm{l}$ of $(10 \mathrm{mM}) \mathrm{dNTPs}, 1.5 \mu \mathrm{lof}(5 \mathrm{mM}) \mathrm{MgCl}_{2}, 5 \mu \mathrm{l}$ of $10 \times$ reaction buffer, $0.25 \mu \mathrm{l}$ of $1 \mathrm{U}$ Taq polymerase (Invitrogen) and water to the total volume $50 \mu \mathrm{l}$. The sequences of the primer pairs used for PCR-amplification of the structural enterocin genes (Ent) A, P, L50B, and B are listed in Table 1. The reaction conditions for EntA detection included 5 min denaturation at $95^{\circ} \mathrm{C}$, followed by 30 cycles of $30 \mathrm{~s}$ at $95^{\circ} \mathrm{C}, 30 \mathrm{~s}$ at $58^{\circ} \mathrm{C}, 30 \mathrm{~s}$ at $72{ }^{\circ} \mathrm{C}$; then by $5 \mathrm{~min}$ at $72{ }^{\circ} \mathrm{C}$ and a cool down to $4{ }^{\circ} \mathrm{C}$. For EntP, L50B and $\mathrm{B}$, the temperature of $56^{\circ} \mathrm{C}$ instead of $58^{\circ} \mathrm{C}$ was used as the annealing temperature. PCR products were visualised by $2 \%$ agarose electrophoresis, containing $1 \mu \mathrm{g}$ of ethidium bromide. Positive control strains for PCR reactions were as follows: E. faecium EK13 (CCM 7419) strain for EntA (Mareková et al. 2003), E. faecium AL41 strain for EntP (Lauková et al. 2003), E. faecium L50 strain for EntL50B and B (Cintas et al. 1998; Casaus et al. 1997). DNA extraction from each strain was obtained by a simple procedure: 1 loopful of bacterial colony (10 $\mu$ l) was resuspended in $30 \mu \mathrm{l}$ of sterile injection water and vortexed for $10 \mathrm{~min}$. Then the supernatant aliquots were used as template DNA.

Table 1. The sequences of the primer pairs used for PCR-amplification of the structural enterocin genes

\begin{tabular}{|c|c|c|c|}
\hline \multirow{2}{*}{ EntA } & $\mathrm{F}$ & 5' - GGT ACC ACT CAT AGT GGA AA - 3' & \\
\hline & $\mathrm{R}$ & $5^{\prime}$ - CCC TGG AAT TGC TCC ACC TAA - 3' & (Aymerich et al. 1996) \\
\hline \multirow{2}{*}{ EntP } & $\mathrm{F}$ & 5' - GCT ACG CGT TCA TAT GGT AAT-3' & \\
\hline & $\mathrm{R}$ & $5^{\prime}$ - TCC TGC AAT ATT CTC TTT AGC - 3' & (Cintas et al. 1997) \\
\hline \multirow{2}{*}{ EntL50B } & $\mathrm{F}$ & 5' - ATG GGA GCA ATC GCA AAA TTA - 3' & \\
\hline & $\mathrm{R}$ & 5' - TAG CCA TTT TTC AAT TTG ATC - 3’ & (Cintas et al. 1998) \\
\hline \multirow{2}{*}{ EntB } & $\mathrm{F}$ & $5^{\prime}$ - CAA AAT GTA AAA GAA TTA AGA TCG - $3^{6}$ & \\
\hline & $\mathrm{R}$ & $5^{6}$-AGA GTA TAC ATT TGC TAA CCC - $3^{6}$ & (Casaus et al. 1997) \\
\hline
\end{tabular}

The antimicrobial activity of the strains was originally tested for 4 indicators such as Streptococcus bovis Sb 36 (Dr. Jonecová, Faculty of Medicine, University of PJ Šafárik, Košice, Slovakia); Enterococcus faecium EF26/42 - own isolate (from rumen contents), Staphylococcus aureus CB40 (University of Veterinary and Pharmaceutical Sciences Brno, Czech Republic), Corynebacterium renale CCM 5740 (Czech Culture Collection of Microorganisms in Brno, Czech Republic). Additionally, the following 11 indicator strains were used: E. avium EA5, L. innocua LMG 13568 (Collection of Microorganisms in Ghent, Belgium), E. faecium $\mathrm{H}_{14 \mathrm{a}}$, Enterococcus sp. $\mathrm{H}_{2}, \mathrm{H}_{4}, \mathrm{LT}_{2}, \mathrm{H}_{12}, \mathrm{H}_{14 \mathrm{~b}}$, Staphyloccocus sp. $\mathrm{SH}_{14}, \mathrm{SH}_{9}$ (isolates from chickens, Salmonella enterica serovar Enteritidis PT4 (Dr. Šiśák, Brno, Czech Republic). Activity was confirmed by the occurrence of inhibitory zone around indicator organisms.

\section{Results}

Before dry-freezing the tested strains were allotted by phenotyping to the species Enterococcus casseliflavus (EC7/EFP7), Enterococcus sp. EP2, EFP5, E. avium EP7 and E. faecium, EEP4, EFP4. However, genotyping using PCR method allotted all six strains to the species E. faecium.

Lactic acid production was detected in the same or very similar amounts in the strains before as well as after dry-freezing in the range values from $0.54 \pm 0.07$ up to $2.0 \pm 0.10$ mmo/l (Table 2). 
Table 2. Lactic acid production and antibiotic sensitivity or resistance of enterococci, isolated from Japanese quails under microgravity conditions before and after 18 years dry-freezing storage

\begin{tabular}{|l|c|c|c|c|c|c|c|c|c|c|c|}
\hline Strains & LA & Van & Kan & Gen & Tct & Stm & Ery & Rif & Amp & Ch & Pn \\
\hline EC 7 $^{1}$ & $0.90 \pm 0.05$ & S & R & R & R & R & S & S & R & nd & R \\
\hline EFP7 $^{*}$ & $0.93 \pm 0.01$ & S & R & S & S & S & S & S & S & S & S \\
\hline EP7 $^{2}$ & $0.93 \pm 0.0$ & S & R & R & S & R & S & R & S & S & R \\
\hline EP7 $^{*}$ & $0.93 \pm 0.02$ & S & R & R & S & R & S & R & S & S & R \\
\hline EFP4 $^{3}$ & nd & S & R & R & R & S & S & R & R & R & nd \\
\hline EFP4 $^{*}$ & $0.86 \pm 0.0$ & S & R & S & S & S & S & S & S & S & S \\
\hline EFP5 $^{4}$ & $0.54 \pm 0.07$ & S & R & S & S & S & S & S & S & S & S \\
\hline EFP5 $^{*}$ & $1.05 \pm 0.02$ & S & R & S & S & S & S & S & S & S & S \\
\hline EP2 $^{5}$ & $0.98 \pm 0.05$ & S & R & S & S & S & S & S & S & S & S \\
\hline EP2 $^{*}$ & $1.24 \pm 0.02$ & S & R & S & S & S & S & S & S & S & S \\
\hline EEP4 $^{6}$ & $2.00 \pm 0.10$ & S & R & R & R & R & R & R & R & R & R \\
\hline EEP4 $^{*}$ & $1.50 \pm 0.07$ & S & R & R & R & R & S & R & S & S & S \\
\hline
\end{tabular}

LA-lactic acid expressed in mmol/l; Van-vancomycin $(30 \mu \mathrm{g})$; Kan-kanamycin $(30 \mu \mathrm{g})$; Gen-gentamicin $(10 \mu \mathrm{g})$; Tct-tetracycline $(30 \mu \mathrm{g})$; Stm-streptomycine $(30 \mu \mathrm{g})$; Ery-erythromycin $(15 \mu \mathrm{g})$; Rif-rifampicin $(30 \mu \mathrm{g})$; Amp-ampicillin $(10 \mu \mathrm{g})$; Ch-chloramphenicol $(30 \mu \mathrm{g})$; Pn-penicilline (10 IU); S-sensitive; R-resistant; nd-not determined; ${ }^{1-6}$ Enterococcus faecium-before dry-freezing; "the strains after re-vitalizing after 18 years

The strains were vancomycin-sensitive and kanamycin-resistant before as well as after dry-freezing (Table 2). Variability in sensitivity to gentamicin, tetracycline, streptomycin, ampicillin, rifampicin, penicillin and chloramphenicol was found among the strains tested even when sensitivity or resistance were compared before and after dry-freezing. The strains were also sensitive to erythromycin; only EEP4 strain was originally resistant, and it was found to be polyresistant.

Table 3. The presence of structural genes for enterocins P, A, B, L50B and inhibitory activity of tested enterococci against the additional indicator microorganisms

\begin{tabular}{|l|c|c|c|c|c|c|c|c|c|c|c|}
\hline Strains & Ent P & A & B & L50B & $\mathrm{Sb}^{1}$ & $\mathrm{Sa}^{2}$ & $\mathrm{EF}^{3}$ & $\mathrm{EA}^{4}$ & $\mathrm{H}_{12}{ }^{5}$ & $\mathrm{Li}^{6}$ & $\mathrm{Cr}^{7}$ \\
\hline EFP7 & - & - & + & - & + & + & + & - & + & - & + \\
\hline EP7 & + & + & + & + & + & + & + & - & + & - & - \\
\hline EFP4 & - & + & - & - & + & + & + & - & - & - & + \\
\hline EFP5 & - & + & - & - & nd & nd & nd & - & - & - & - \\
\hline EP2 & - & + & + & + & + & + & nd & - & + & - & + \\
\hline EEP4 & - & + & + & + & + & + & $\mathrm{nd}$ & - & + & - & + \\
\hline
\end{tabular}

+ : the presence of gene or inhibition of the indicator organism; -: absence of the structural gene or inhibition of the indicator; 'Sb-Streptococcus bovis 36 (Dr. Jonecová, Faculty of Medicine, University of PJ Šafárik, Košice, Slovakia); ${ }^{2}$ Staphylococcus aureus CB40-Czech Culture Collection of Microorganisms, CCM, Brno; ${ }^{3}$ Enterococcus faecium EF26/42, ${ }^{4}$ E. avium EA5 (Dr. Lauková, IAP SAS, Slovakia); ${ }^{5}$ Enterococcus sp. $\mathrm{H}_{12}-($ Dr. Michlovičová, IAP SAS); ${ }^{6}$ L. innocua LMG 13568-Ghent, Belgium; $\mathrm{Cr}^{7}$-Corynebacterium renale CCM 5740 ; Enterococcus sp. $\mathrm{H}_{2}, \mathrm{H}_{4}, \mathrm{LT}_{2}, \mathrm{H}_{14 \mathrm{~b}}$, E. faecium $\mathrm{H}_{14 \mathrm{a}}$, Staphylococcus sp. $\mathrm{SH}_{14}, \mathrm{SH}_{9}$ (Dr. Michlovičová, IAP SAS, Košice) S. enterica serovar Enteritidis PT4 were not inhibited by the tested strains; besides E. faecium EEP4 strain which inhibited the strains indicated in the table as well as enterococci and staphylococci from chickens (together 13 strains among 15 tested).

Each of the six strains possesses at least one structural enterocin gene among those tested (Table 3). The structural genes for ent A, P, B and L50B production was detected in E. faecium EP7 strain. E. faecium EP2 and EEP4 have the genes for ent A, B, L50B production. The gene for ent $\mathrm{P}$ was detected only in the strain EP7. The most detected was ent A gene (in 5 isolates) followed by the gene for ent B production (in 4 isolates) and L50B (in 3 isolates).

All strains inhibited the growth of at least 4 out of 15 indicators (Table 3 ). The principal (most sensitive) indicators generally used in our study, E. avium EA5 strain as well as 
L. innocua LMG 13568, were resistant to the strains tested. The growth of S. enterica PT4 was not inhibited by the substances produced by the tested enterococci from Japanese quails. The growth of $S$. aureus CB40 as well as C. renale CCM 5740 was inhibited (before dry-freezing).

\section{Discussion}

It seems (also from our previous studies) that the phenotyping of E. faecium is in harmony with its genotyping (unpublished data). However, there were differences found in phenotyping and genotyping of the species E. casseliflavus or E. avium (Kirschner et al. 2001). E. faecium is a frequently determined species from the genus Enterococcus among poultry faecal samples (Strompfová et al. 2003, 2007; Tejedor-Junco et al. 2005; Lauková et al. 2008). There are suggestions that especially plasmid-encoded properties such as antibiotic resistance or bacteriocin production could be missing or changed by subsequent passaging of the strains when they are re-vitalized after storage (Lauková and Kuncová 1991). Under our conditions, unchanged LA amounts were detected in enterococci after their long-term storage. This stability could be probably supported by the chromosomal encoding of LA as has been found e.g. for rifampicin resistance in enterococcci (Lauková and Kuncová 1991; Rice et al. 1991). Detection of the structural enterocin genes by PCR is a method that was not available years ago. Therefore it was interesting to determine it when the strains tested were found to produce an antimicrobial substance. There are differences in the ent genes occurrence among $E$. faecium species isolated from different ecosystems. Strompfová and Lauková (2007) reported the presence of only ent $\mathrm{A}$ and $\mathrm{P}$ structural genes among 5 bacteriocin producing $E$. faecium strains isolated from the caecum, ileum and crop of chickens. Moreover, contrary to the results presented here, ent $\mathrm{P}$ gene was the most frequently occurring gene among 234 enterococcal strains from different sources (Strompfová et al. 2008). Among rabbit enterococci, ent A, P, L50B genes were determined but not ent B (Simonová and Lauková 2007). On the other hand, ent B gene was found in enterococci isolated from horses (Lauková et al. 2008). Taking into account bacteriocin production and structural genes detection, EEP4 strain was the most active; although it could be probably discussed that it produces one among enterocins tested and/or a new substance; it will be researched in more detail in our further studies. Interestingly, $S$. aurues CB40 as well as C. renale CCM 5740 were mostly inhibited before dry-freezing. That is, bacteriocin production as well as antibiotic resistance are plasmidencoded properties which as formerly mentioned could be lost by subsequent manipulation (Lauková and Kuncová 1991). In the case of our strains this phenomenon could be hypothetically supposed, although in preliminary studies no plasmids were determined (unpublished data).

Changes in antibiotic sensitivity or resistance in the strains after strain re-vitalization could be explained by different ways; e.g. by the molecular way - the structural gene transport (Lauková et al. 1990), or pragmatically by better quality of modern disks. It is also interesting that polyresistant EEP4 strain showed the best antimicrobial activity; it could be due to bacteriocin but also due to LA production (the highest value among 6 strains tested). The knowledge on bacteriocin production among the isolates presented give us opportunity to search for the probable new substance, to spread information in association with space research as well as to select the strain for other e.g. probiotic testing. It can be concluded that the tested enterococci maintained stability of the properties determined before as well as after their long-term storage by dry-freezing; moreover, additional properties were determined.

\section{Enterokoky z japonských prepelíc vystavených podmienkam mikrogravitácie a stabilita ich vlastností}

Enterokoky izolované z hrvol'a a céka japonských prepelíc (vystavených po dobu 7 dní podmienkam mikrogravitácie) boli lyofilizované pre dlhodobé uskladnenie. Kmene boli 
izolované z japonských prepelíc po ich návrate z letu na palube orbitálnej stanice Mir počas experimentu v auguste roku 1991v rámci výskumného vesmírneho programu InterkozmosInkubátor 2. Pretože taxonómia ako aj poznatky o bakteriocínoch, najmä o tých, ktoré sú produkované enterokokmi sa rokmi vyvíjali, ciel'om predkladanej práce bolo genotypizáciou overit' taxonomickú príslušnost' uskladnených kmeňov, prehodnotit' ich stabilitu a vlastnosti po dlhodobom uskladnení ako aj zistit' u nich prítomnost' génov pre produkciu niektorých doposial' známych enterocínov. Vyselektovaných 6 kmeňov bolo genotypizáciou priradených $\mathrm{k}$ druhu Enterococcus faecium. Intenzita produkcie kyseliny mliečnej ostala nezmenená po dlhodobom skladovaní testovaných kmeňov. Enterokoky boli citlivé na vankomycín a rezistentné na kanamycín. Variabilita v citlivosti či rezistencii k testovaným antibiotikám bola zistená pred i po ich skladovaní lyofilizáciou. Každý testovaný kmeň obsahoval aspoň jeden štrukturálny gén pre produkciu testovaného enterocínu. Štrukturálne gény pre produkciu enterocínov A, P, B, L50B boli detegované u kmeňa E. faecium EP7. Kmene EP2, EEP4 obsahovali gény pre enterocíny A, B, L50B. Gén pre produkciu enterocínu $\mathrm{P}$ bol zistený len u kmeňa EP7. Najčastejšie bol detegovaný ent A gén, potom gény pre produkciu enterocínov B a L50B. Všetky kmene inhibovali rast najmenej 4 z 15 indikátorových mikroorganizmov. Enterokoky si zachovali svoje vlastnosti i po dlhodobom skladovaní v lyofilizovanej forme. Naviac, boli u nich detegované i d'alšie vlastnosti.

\section{Acknowledgement}

This study is dedicated to the memory of Professor Koloman Bod'a who founded the Institute of Animal Physiology in Košice and who worked with great enthusiasm for many years in the space scientific programme Interkozmos. We also thank Mrs. Margita Bodnárová for her excellent technical assistance. A part of the study was supported by the Vega Project 2/0008/08.

\section{References}

Aymerich T, Holo H, Havarstein LS, Hugas M, Garriga M, Nes IF 1996 Biochemical and genetic characterization of enterocin A from Enterococcus faecium, a new antilisterial bacteriocin in the pediocin family of bacteriocins. Appl Environ Microbiol 62: 1676-1682

Bod'a K 1979: Will yielding animals fulfil their function also under cosmic conditions? (in Slovak), Tech. práca XXXI: 23-27

Bod'a K, Sabo V, Juráni M, Gurjeva TS, Kočišová J, Košţál L', Lauková A, Dadasheva OA 1992: Embryonic development and behaviour of Japanese quail exposed to microgravity. Acta Vet Brno 61: 99-107

Cigánková V, Lenhardt L', Zibrín M, Kočišová J, Tomajková E, Sabo V, Bod’a K, Dadaševa OA, Gurjeva TS 2000: Morphological changes in the small intestine of Japanese quails exposed to space-flight conditions. (in Slovak) Slov Vet J 25: 222-227

Casaus P, Nilsen T, Cintas LM, Nes IF, Hernandez PE, Holo H 1997: Enterocin B, a new bacteriocin from Enterococcus faecium T136 which can act synergistically with enterocin A. Microbiol 143: 2287-2294

Cintas LM, Casaus P, Havarstein LV, Hernandez PE, Nes IF 1997: Biochemical and genetic characterization of enterocin P, a novel sec-dependent bacteriocin from Enterococcus faecium P13 with a broad antimicrobial spectrum. Appl Environ Microbiol 63: 4321-4330

Cintas LM, Casaus P, Holo H, Hernandez PE, Nes IF, Havarstein LS 1998: Enterocins L50A and L50B, two novel bacteriocins from Enterococcus faecium L50 are related to staphylococcal haemolysins. J Bacteriol 180: 1988-1994

Cintas LM, Casaus P, Herranz C, Havarstein LS, Holo H, Hernández PE, Nes IF 2000: Biochemical and genetic evidence that Enterococcus faecium L50 produces enterocins L50A and L50B, the sec-dependent enterocin $\mathrm{P}$, and a novel bacteriocin secreted without an N-terminal extension turned enterocin. Q J Bacteriol 182: 6806-6814

De Vuyst L, Foulquié Moreno MR, Revets H 2003: Screening for enterocins and detection of hemolysin and vancomycin resistance in Enterococci of different origins. Int J Food Microbiol 84: 299-318

Franz CHMPA, Van Belkum MJ, Holzapfel WH, Abriouel H, Gálvez A 2007: Diversity of Enterococcal bacteriocins and their grouping in a new classification scheme. FEMS Microbiol Rev 31: 293-310

Juráni M, Bod’a K, Koštál L', Somoyiová E, Lamošová D, Výboh P, Ambruš P, Baumgartner J 1988: Selection of Japanese quail line resistant to hypodynamy. Physiologist S31: 140-142

Kirschner C, Maquelin K, Pina P, Ngo Thi NA, Choo-Smith LP, Sockalingum GD, Sandt C, Ami D, Orsini F, Doglia SM, Allough P, Mainfait M, Puppels GJ, Naumann D 2001: Classification and identification of 
enterococci: a comparative phenotypic, genotypic and vibrational spectroscopic study. J Clin Microbiol 39: 1763-1770

Lauková A, Kuncová M, Kmet' V 1990: Isolation of several conjugative plasmids of the rumen bacteria Enterococcus faecium. Biológia (Bratislava) 45: 533-538

Lauková A, Kuncová M 1991: Lactic acid production and urease activity of rumen strains of Enterococcus faecium and their genetic stability. Vet Med Prague 36: 335-340

Lauková A, Kmet’ B, Bod'a K 1991: Microflora of Japanese quail under space conditions. Curr Trends in Cosmic Biol 2: 225-232

Lauková A, Bod'a K, Kmet' V 1993a: A note on the influence of microgravity on the microbial endoecosystem of Japanese quail. J Anim Feed Sci 1: 295-301

Lauková A, Kmet' V, Bod'a K 1993b: Antimicrobial activity of bacteriocin-like substances produced by bacterial strains isolated from crop and caecum of Japanese quail under microgravity conditions. Acta Vet Brno Suppl 6, 62: S83-S86

Lauková A, Kmet' V, Bod'a K 1993c: Production of bacteriocin-like substances by strains of enterococci, streptococci and staphylococci isolated from Japanese quail. Czech J Anim Sci (Živ Výr) 38: 53-59

Lauková A, Marounek M, Bod'a K 1995: Characteristics of enterococci and staphylococci isolated from the crop and caecum of Japanese quails exposed to microgravity conditions. Vet Med -Czech 40: 317-321

Lauková A, Turek P, Mareková M, Nagy J 2003: Use of ent M, new variant of ent P to control Listeria innocua in experimentally contaminated Gombasek sausage. Arch Lebensmittelhyg 54: 25-48

Lauková A, Simonová M, Strompfová V, Štyriak I, Ouwehand, AC, Várady M 2008: Potential of enterococci isolated from horses. Anaerobe 14: 234-236

Lauková A., Haviarová M., Strompfová V, PogánySimonová M., Nad’ P.: Effect of phyto-additives against enterococci isolated from turkeys. In Proceedings from the conference -Hygiena Alimentorum XXX, 13-15 of May, 2009, Štrbské Pleso, pp.101-103

Mareková M, Lauková A, De Vuyst L, Skaugen M, Nes IF 2003: Partial characterization of bacteriocins produced by environmental strain Enterococcus faecium EK13. J Appl Microbiol 94: 523-530

Mareková M, Lauková A, Skaugen M, Nes IF 2007: Isolation and characterization of a new bacteriocin, termed enterocin M, produced by environmental isolate Enterococcus faecium AL41. J Ind Microbiol Biotechnol 34: 533-537

National Committee for Clinical Laboratory Standards 2002: Performance standards for antimicrobial disk and dilution susceptibility tests for bacteria isolated from animals; approved standard-second edition, NCCLS Document M31-A2. National Committee for Clinical Laboratory Standards, Wayne, PA, USA

Pryce JD 1969: A modification of the Barker-Summerson method for the determination of lactic acid. Analyst 94: $1151-1152$

Simonová M, Lauková A 2007: Bacteriocin activity of enterococci from rabbits. Vet Res Com 31: 143-452

Rice IB, Ellopoulos GM, Weunersten G, Goldmann D, Jacoby GA, Moellering RC Jr. 1991: Chromosomally mediated beta-lactamase production and gentamicin resistance in Enterococcus faecalis. Antimicrob Agents Chemother 35: 272-276

Skalka B, Pillich J, Pospíšil L 1983: Further observations on Corynebacterium renale as an indicator organism in the detection of exfoliation-positive strains of Staphylococcus aureus. Zbl Bakteriol Hyg A256: 168-174

Strompfová V, Lauková A, Mudroňová D 2005: Effect of bacteriocin-like substance produced by Enterococcus faecium EF55 on the composition of avian gastrointestinal microflora. Acta Vet Brno 72: 559-564

Strompfová V, Lauková A 2007: In vitro study on bacteriocin production of Enterococci associated with chickens. Anaerobe 13: 228-237

Strompfová V, Lauková A, Simonová M, Marciňáková M 2008: Occurrence of the structural enterocin A,P,B, L50B genes in enterococci of different origin. Vet Microbiol 132: 293-301

Tejedor-Junco MT, Afonso-Rodríguez O, Martín-Barrasa JL, González-Martín M 2005:Antimicrobial susceptibility of Enterococcus strains isolated from poultry faeces. Res Vet Sci 78: 33-38

Woodford N, Egelton MC, Morrison D 1997: Comparison of PCR with phenotypic methods for the speciation of Enterococci 47: New York, Plenum Press, pp. 405-409 